Нишский государственный университет, Факультет искусств, ул. Кнегиње Љубице, д. 10, г. Ниш 18000, Республика Сербия; dzdravicmihailovic@yahoo.com

Аннотация. Известное произведение сербского композитора Станислава Бинички (1872-1942 гг.) «Марш на Дрину» было написано в честь побед сербских военных в начале Первой мировой войны. Одно время, в связи с большой популярностью, оно рассматривалось в качестве одного из вариантов гимна Социалистической Федеративной Республики Югославии, но также и как символ сербского национализма, что часто вызвало полемику и сильно повлияло на судьбу произведения. В работе представлена ретроспектива контекста, в рамках которого композиция проявляла себя в течение столетнего периода с целью объяснения обусловленности судьбы музыкального произведения социальноисторическими переменами.

Ключевые слова: «Марш на Дрину»; музыкальное произведение; Сербия; национализм

Для цитирования: Здравич-Михайлович Д. Феномен судьбы музыкального произведения: один век «Марша на Дрину» // Научный результат. Социальные и гуманитарные исследования. 2019. Т. 5. № 4. С. 51-61. DOI: 10.18413/2408932X-2019-5-4-0-5

\title{
D. Zdravić-Mihailović
}

THE PHENOMENON OF A MUSICAL PIECE: ONE CENTURY OF "THE MARCH ON THE DRINA"

University of Nis, Faculty of Arts, 10 Kneginje Ljubice, Nis 18000, Serbia; dzdravicmihailovic@yahoo.com

\begin{abstract}
In this work we review the occurrence and future of a famous Serbian composition "The March on the Drina" by a Serbian composer Stanislav Binicki (1872-1942). The author of this famous march was inspired by victories of the Serbian army against Austria-Hungary after the battle of Cer (from 12 to 24 August 1914). The composition became popular and it was a faithful companion of the Serbian army during World War I, but after some time it started to fall into oblivion. Today, a hundred years after the making of the composition, it's significant to point out its social and cultural importance during the last century. Based on historical facts, we can observe contextualization of "The March on the Drina", initiated by socio-political events and draw attention to the true motive of its origin. In that way we can contribute that real musical qualities, as patriotic drives overcome the daily-political turmoil.
\end{abstract}

Keywords: "March to river Drina"; musical composition; Serbia; nationalism 
For citation: Zdravić-Mihailović, D. (2019), "The phenomenon of a musical piece: one century of "The March on the Drina", Research Result. Social Studies and Humanities, 5 (4), 51-61, DOI: 10.18413/2408-932X-2019-5-4-0-5

\section{1. Введение}

В истории музыки не редкость, когда отдельные произведения прочно связаны с определенным общественно-политическим контекстом, так как вне этого контекста идентичность и значение произведения искусства трудно понять и оценить. Можно сказать, что в сербской среде не существует другого музыкального произведения, на которое бы настолько повлияла историческая ситуация, как «Марш на Дрину».

Развитие судьбы музыкального произведения от его создания в знак поддержки храбрым сербским воинам в начале Первой мировой войны, обретения статуса любимой песни сербского народа и неофициального гимна до произведения, нежелательного для публичного исполнения, очевидно, заслуживает особого внимания. После более ста лет существования «Марша на Дрину» можно сказать, что на неоднородное восприятие композиции, особенно на Балканах, повлияло множество исторических факторов.

\section{2. Жизнь и творчество Станислава Бинички}

Даже помимо заслуги создания знаменитого «Марша на Дрину», деятельность композитора Станислава Бинички (1872-1942) оставила заметный след в культурной жизни Сербии. Он родился в 1872 году в селе Ясика рядом с городом Крушевац. Первый свой музыкальный опыт он получил, посещая гимназии в городах Нише и Белграде, а начальные музыкальные знания приобрел в Нише от чешских музыкантов. Игре на скрипке учился у Фридриха Брунетти (Brunetti), а флейту осваивал под руководством военного музыканта Павла Гайича. После переезда в Белград, где он посещал начальные классы реального училища, Станислав Бинички брал уроки музыки у Йосифа
Свободы (Svoboda). В 1890 году он начал обучение на кафедре физикоматематических наук философского факультета в Белграде. Станислав Бинички активно занимался музыкой и во время обучения на философском факультете, став членом уважаемых тогда певческих обществ: Белградского певческого общества и Академического певческого общества «Обилич», чьими хормейстерами были Йосиф Маринкович и Стеван Стоянович Мокраняц (Дујовић, 2014).

После окончания философского факультета Бинички становится преподавателем гимназии в городе Лесковац, но вскоре уезжает в Музыкальную академию, в Мюнхен, где создает несколько произведений для смешанного хора. После возвращения в Белград в 1899 году он становится военным дирижером и основывает первый большой симфонический оркестр, получивший название «Белградский военный оркестр», регулярно концертирует с ним. Вместе со Стеваном Стояновичем Мокраньцем и Костом Манойловичем в 1899 году основывает Сербскую музыкальную школу (сегодня это музыкальная школа «Мокраняц») и становится в ней преподавателем. Вскоре, в 1904 году, он основывает «Оркестр Королевской Гвардии», в котором работает дирижером до 1920 года. В качестве регента он активно участвовал в деятельности Белградского певческого общества и «Обиличе», Типографского певческого общества «Якшич» и певческой группы «Станкович» (Đurić Klajn, 1971).

Во время Первой мировой войны, как дирижер оркестра Королевской гвардии, Бинички организует ряд концертов на Корфу и в Салониках, а затем - в Париже, Лионе, Бордо, Марселе, Ницце и др. После успеха во Франции оркестр с ноября 1916 года вновь возвращается в Салоники, где Бинички на протяжении всей войны 
неустанно концертирует. В Салониках с 1916 года была расположена резиденция Оркестра королевской гвардии, где у членов оркестра был свой дом и здание, в котором они репетировали. Выступления оркестра были весьма интенсивны - почти ежедневно оркестр принимал участие во всех значимых концертах в городе и в окрестностях.

«Марш на Дрину» на Солунском фронте, а также во время гастролей сербского военного оркестра во Франции завоевал большую популярность, поэтому его исполняли и оркестры союзных армий. Принимая во внимание обстоятельства, при которых проводились концерты, и то, что публика в основном состояла из раненых, можно сказать, что программа полностью соответствовали своему назначению. Большинство произведений в репертуаре составляла солунская военная музыка и марши, среди которых был и «Марш на Дрину» (Пејовић, 1991).

После войны Бинички с тем же оркестром отправляется в большое турне по всей Югославии. Он был первым директором вновь основанной Оперы в Белграде, одновременно работая и руководителем хора певческого общества «Станкович» и преподавателем в музыкальной школе. С 1924 года он прекращает свою публичную творческую деятельность и полностью посвящает себя сочинению музыки ${ }^{1}$.

\footnotetext{
${ }^{1}$ Из оркестровых композиций, созданных Бинички, необходимо отметить увертюру «Из моего родного края» и военные марши, а из произведений для театра - оперу «На заре», написанную в 1903 году на текст Бранислава Нушича (первую поставленную на сцене сербскую оперу), музыку для драмы «Путешествие вокруг света», произведение «Наход», переработку произведения «Джидо» Даворина Енко, музыку для сказки Нушича «Лиляна и ель», увертюру и оркестровое интермеццо для драмы Войновича «Эквиноцио». Он писал произведения для хора, а также песни для сольного исполнения, самыми известными из которых являются «Гривна», «Мне бы глаза твои», «Когда увидел я глаза твои», «В липовой роще» и т.д. Что касается жанра духовной музыки - стоит упомянуть его «Литургию», «Отпевание» и «Благодарение».
}

В первые два десятилетия XX века Бинички был не только самым активным лицом всей музыкальной жизни в Сербии, но и инициатором многих пионерных движений. Для понимания специфики вклада Станислава Бинички в историю сербской музыки важны два основных момента. Первый относится к рассмотрению значения совокупной деятельности Бинички его дирижерской, организаторской и педагогической работы. Даже поверхностный обзор этой активности говорит об исключительной трудовой энергии и высоком уровне, которого он достиг в разных областях. Второй момент относится к его творчеству (Маринковић, 2007).

Можно сказать, что выдающиеся сербские музыковеды и теоретики солидарны в оценке значительного вклада Станислава Бинички в обеих сферах. По словам Властимира Перича (Peričić, 1969), наряду с тем, что самых значительных результатов Бинички достиг в исполнительской и организационной области, он и как композитор занимает важное место в истории сербской музыки. Творчество Бинички стало связующим звеном между поколением Маринковича и Мокраньца, преимущественно ориентированных на вокальную музыку, и группой деятелей искусства, которые начали разработку более крупных инструментальных сценических форм, из которых наиболее выдающиеся это Петар Коньович, Милое Милоевич и Стеван Христич. Хотя значительная часть произведений Бинички и берет за основу сербский фольклор, композитор также привнес в музыкальное искусство многие элементы, которые были типичны для городской культуры того времени, то есть адаптировал фольклор к городскому вкусу и интерпретировал сквозь призму городского сентиментализма. По словам известного сербского музыковеда Стане Джурич Клайн, композиторский корпус сочинений Станислава Бинички не был велик, но отвечал духу, атмосфере и потребностям своего времени, особенно старой белград- 
ской среде, которая «только что выросла на базе сельского и ориентального примитивизма и мелодика которой, окрашенная меланхолией и севдахом ${ }^{2}$, быстро западала в душу» (Đurić Klajn, 1981: 242). Свои opкестровые композиции и другие произведения Бинички писал под влиянием западноевропейского неоромантизма, но мировую славу приобрел благодаря «Маршу на Дрину».

\section{3. Общественно-политические события на Балканах в XX веке}

Можно сказать, что на судьбу «Марша на Дрину» больше всего повлиял исторический путь сербского государства за прошедшие сто лет, поэтому без учета общественно-политических перемен невозможно понять разночтения в понимании этого популярного марша.

Сербия как самостоятельное государство под давлением ультиматума было вынуждено вступить в войну против австро-венгерской монархии в 1914 году. В составе австро-венгерской армии этого периода были и соединения, состоящие из представителей южнославянских народов (хорватов, словенцев, боснийцев), которые проживали в юго-восточной части существовавшего тогда монархического государства, граница которого с Сербией проходила вдоль реки Дрина. После Первой мировой войны, 1 декабря 1918 года, было создано Королевство сербов, хорватов и словенцев - демократическая парламентарная монархия во главе с династией Караджорджевичей. Сербия отказалась от своей независимости ради новообразованного государства, которое строила с теми, кто только вчера был ее противником на поле боя.

Вторая мировая война, помимо оккупации балканских стран Германией, Италией, Болгарией и Венгрией и распада Ко-

\footnotetext{
${ }^{2}$ Севдах - настроение, состояние ума и души, вызванное слушанием песен севдалинок, представляющих транснациональный традиционный фольклорный жанр городской любовной песни в странах бывшей Югославии.
}

ролевства сербов, хорватов и словенцев, привела к большой гражданской войне на всей его территории. Словения была присоединена к Германии, Черногория и часть адриатического побережья - к Италии, а Македония - к Болгарии. Сербия была поделена между Германией, Болгарией и Венгрией, а Хорватия как союзник присоединилась к основным силам (Германии, Королевства Италии и Японской империи). Так в 1945 году, после поражения фашизма, была сформирована новая, на этот раз Социалистическая Федеративная Республика Югославия. После смерти социалистического лидера, президента Социалистической Федеративной Республики Югославии Иосипа Броз Тито, начался развал страны, кульминацией которого стала большая гражданская война 1991-1995 годов. Официально Югославия прекратила свое существование в 1992 году, но ее наследницами стали Сербия и Черногория, которые продолжили существование в рамках нового общего государства под названием Союзная Республика Югославия. Это государство просуществовало до 2003 года, когда союз был расторгнут на основании соглашения. Сербия после восьмидесяти пяти лет вернула свою самостоятельность и государственность.

Благодаря историческим переходам от самостоятельного государства к объединенному Королевству сербов, хорватов и словенцев и от формирования до распада Югославии, все символы сербской национальной идентичности, а среди них и культурное наследие сербского народа, были переинтерпретированы.

\section{4. «Марш на Дрину» в контексте соци- альных перемен в течение XX века}

Творчество любого народа прочно связано с общественно-политическими событиями. По словам выдающегося сербского музыковеда Соньи Маринкович (Маринковић, 2007), начало XX века в истории сербской музыки было ознаменовано продолжением традиции предыдущего периода, которую, несмотря на раз- 
личные формы проявления, можно подвести под единый знаменатель, - это формирование специфической национальной идентичности. Эта тенденция была обусловлена общенародным стремлением к освобождению и объединению, которые в бурных политических событиях проявились как неизбежный императив, и поэтому всё происходящее было в его русле. В этом смысле мы можем сказать, что и «Марш на Дрину» занимает свое особенное место не только в сербской музыке, но и во всеобщей истории.

«Марш на Дрину» был написан в 1914 году в честь победы сербского войска над австро-венгерской армией после битвы при Цере (12-24 августа 1914 года) ${ }^{3}$. Запись о появлении композиции оставил Димитрие Джорджевич, военный музыкант, ученик и последователь Станислава Бинички. В своих воспоминаниях он утверждает, что Бинички написал этот марш, когда Сводный полк под командованием полковника Миливое Стояновича Брке обратил в бегство через Дрину превосходящую их по численности австровенгерскую армию ${ }^{4}$.

Как уже сказано, этот марш был очень популярен потому, что композитор вместе с оркестром Королевской гвардии, дирижером которого он являлся и который наряду с другими исполнял и эту композицию, таким образом способствовал распространению духа патриотизма - как на поле боя, так и на территории дружественных стран, которые приняли сербских раненых (прежде всего, в Греции и во Франции). В связи с повсеместным признанием и большой популярностью, не удивительно, что Дринская дивизия 12 октября

\footnotetext{
${ }^{3}$ Несмотря на то, что могут встретиться данные о том, что «Марш на Дрину» появился на фронте, согласно некоторым новейшим источникам, он был написан в 1914 году в Вальево, где Бинички оказался вместе с Верховным главнокомандованием (Puzović, 2013).

${ }^{4}$ Полковник Стоянович, легендарный командир 2го железного полка «Князь Михаило» участвовал в битве при Цере на ключевой позиции в Текерише, погиб в Колубарской битве.
}

1918 года победно вошла в только что освобожденный город Ниш под звуки «Марша на Дрину». Несмотря на то, что композиция быстро нашла свое место в культурной жизни Сербии того времени, в конце первой половины XX века ее начали постепенно забывать.

После второй мировой войны «Марш на Дрину» становится нежелательной композицией и предается забвению вплоть до 1961 года, когда Иво Андрич был приглашен в Швецию для вручения Нобелевской премии по литературе. Сербский нобелевский лауреат взял с собой в Стокгольм пластинку с этой композицией, которую воспроизвели во время вручения награды. Так этот марш вновь стал и широко известным, и весьма популярным произведением. Вскоре шведский трубач Йорген Петерсен (Jörgen Petersen) записал эту мелодию в виде сингла, но еще бо̀льшую популярность марш обрел в 1963 году, когда его записал датский гитарист и победитель конкурса песни «Евровидение» Юрген Ингманн (Jørgen Ingmann). После большого успеха в Дании издательство Полидор (Polydor) выпустило пластинку и для своего рынка. «Марш на Дрину» в том же 1963 году записал и немецкий оркестр Хорста Венде (Horst Wende) ${ }^{5}$. По данным чарта Билборд (Billboard), этот сингл был хитом в 1963 году: Drina Marsch в исполнении Ингманна занимал второе место. По приглашению Полидора в Швецию приезжает ансамбль «Урошевич», в котором играл известный скрипач Властимир Павлович Царевац. Для шведского рынка они записывают самую известную версию марша, которая появилась в Югославии несколькими годами позднее. В это время «Марш на Дрину» стал известен и в Америке, его популяризации особенно способствовали сёрф-рок группы шестидесятых, которые исполняли танцевальную версию этого марша на вечеринках. Самые известные из этих групп - The Spotnicks, The Jokers и The Shadows (Puzović, 2013).

\footnotetext{
${ }^{5}$ Режим доступа:

https://www.youtube.com/watch?v=Fo5HEsRdYQw
} 
В начале шестидесятых годов прошлого века «Марш на Дрину», как нам представляется, везде в мире был более известен, чем в Сербии. Заслуга его «второй жизни» на Балканах принадлежит режиссеру Жике Митровичу, который в 1964 году снял одноименный фильм. Музыку для фильма переработал известный сербский композитор Василий Мокраньяц (1923-1985). Хотя власти и с подозрением восприняли этот фильм, а заказные негативные критики назвали его бездарным и неисторическим, он снискал популяр- ность и сегодня является одним из культовых сербских фильмов.

На Балканах до 1964 года исполняли инструментальную версию марша. Торжества по поводу пятидесятилетия битвы при Цере стали поводом, чтобы к музыке «Марша на Дрину» был написан текст. Наследницы авторских прав, четыре дочери композитора, выбрали текст, который написал Милое Попович, журналист и писатель, по образованию юрист. Годом позже была записана и пластинка с вокальной версией этого марша.

\section{МАРШ НА ДРИНУ (короткая версия текста)}

У бој, крените јунаци сви

Крен'те и на жал'те живот свој

Цер да чује твој, Цер нек види бој

А река Дрина славу, храброст

И јуначку руку оца, сина.

Пој, пој Дрино, водо хладна ти

Памти, причај кад су падали

Памти храбри строј

Који је пун огња, силне снаге

Протерао туђина са реке наше драге.

Пој, пој Дрино, причај роду ми

Како смо се храбро борили

Певао је строј, војево се бој

Крај хладне воде

Крв је текла

Крв се лила

Дрином због слободе.

Очень быстро композиция стала весьма популярна в мире - в разных аранжировках, даже как твист. Международную известность она получила благодаря изданиям в Германии, США, Канаде и многих странах Латинской Америки и Азии (Павловић, 1990). «Марш на Дрину» имеет свыше 20 национальных и иностранных аранжировок и 27 различных многодисковых изданий по всему миру.

Уровень популярности «Марша на Дрину» не равномерно распределен по

\footnotetext{
6 Поэтическое переложение Татьяны Андреевны Смотровой
}

Герои, все идите в бой, Идите, не щадя и жизни! Наш Цер увидит, Цер услышит бой, А река Дрина - нашу храбрость, имя Руки геройской, сына и отца.

Пой, Дрина, пой, полная ледяной водой! Помни и говори, как падали, Помни, полный огня героев своих ты строй, Мощные силы чужие, что прогнаны От тебя, дорогой ледяной реки.

Пой, Дрина, пой, расскажи обо мне родным!

Как мы храбро близ тебя сражались,

Как пел строй, как шел бой

И в тебя, с ледяной водой,

Лилась кровь,

Текла кровь

По тебе, Дрина, за свободу... ${ }^{6}$

разным периодам XX века, но в целом можно сказать, что он был регулярной составной частью репертуара хоров и оркестров. Из-за упомянутого фильма, как и вокально-инструментальной версии, он стал близок и младшим поколениям, и таким образом полностью «встроился» в сербскую национальную идентичность.

Восьмидесятые годы прошлого века характеризовались новой волной популярности «Марша на Дрину», когда известный рок-музыкант Радомир Михайлович Точак, записавший этот марш в стиле рок, привлек юную публику. Помимо этого, «Марш на 
Дрину» исполнял Джонни Штулич, а также словенская группа Лайбах (Laibach), которая даже записала его на 16-ти альбомах. Эти данные указывают на то, что «Марш на Дрину» постепенно выходил за рамки сербского фольклора и становился частью новой городской культуры.

В начале восьмого десятилетия XX века в Сербии начались разговоры о необходимости создания республиканского гимна. Власти того времени считали, что нужно не объявлять специальный конкурс, а просто выбрать одну из актуальных патриотических песен, причем чаще всего упоминалась известная композиция Станислава Бинички. Однако отдельные представители власти периодически указывали на то, что эта и схожие песни способствуют тенденции роста волны сербского национализма, а на одном из очередных совещаний товарища Тито с руководителями Социалистической Республики Сербия, проводившихся с 9 по 12 октября 1972 года в Белграде, кто-то из членов совета обратил внимание на вызывающий беспокойство хороший прием композиций «Марш на Дрину», «Тамо далеко...» и других, особенно в публичных местах и в кафанах. По его словам, как только музыканты в кафане ${ }^{7}$ видели, что туда входят функционеры и политики, они начинали играть «Марш на Дрину». Товарищ Тито на это ответил, что он редко ходит в кафаны, но, когда всё же приходит туда, ему тоже играют «Марш на Дрину», и ему это не мешает (Маркович и Кржавац, 1985). Этот разговор, как и многочисленные дискуссии, связанные со статусом популярных композиций, показывает, что вопрос национализма и сербского музыкального фольклора стоял особенно остро. По словам музыковеда

\footnotetext{
7 «Кафана»- термин, используемый в большинстве бывших югославских стран для городского или сельского социального места сбора типа бистро, в которых в первую очередь подают алкогольные напитки и кофе, а также легкие закуски и другие блюда. В большинстве кафан присутствует живая музыка.
}

Сонье Маринкович, каждое исполнение «Марша на Дрину», особенно во времена, когда он был запрещен, сербы воспринимали как продолжение традиции побед при Цера и на Колубаре. Марш, который Станислав Бинички сочинял под пушечной канонадой в 1914 году, гордо хранил память о страданиях и победе в Великой войне и тогда, когда о них нужно было молчать. Музыка от библейских иерихонских труб до настоящего времени осталась частью военного арсенала, но мало мелодий, которые, как «Марш на Дрину», дословно перешли в фольклор (Puzović, 2013).

\section{5. «Марш на Дрину» между национализмом и музыкальным воспеванием национального}

Когда некое произведение искусства каким-то образом становится атрибутом всех общественно-политических турбуленций, несомненно, что его контекстуализация обусловливается именно этими событиями, так между объектом (музыкальным произведением) и многочисленными событиями возникают крепкие причинно-следственные связи. Неразрывная связь между «Маршем на Дрину» и сербским национализмом установилась от момента его возникновения (в начале Первой мировой войны) и поддерживалась благодаря широкой популярности красивой музыки, которая была специфическим образом объединена с музылальным воспеванием национального.

В условиях, когда некая музыкальная композиция получает статус «национальной песни», необходимо уточнять рамки значения понятия национализм. Одно из объяснений этому понятию дал чехословацкий национальный вождь Томаш Масарик, определив его как «каждый такой взгляд, который нацию рассматривает как наивысшую политическую ценность» (Sociološki rečnik, 2007: 342). Однако можно сказать, что имеет место единство мнений по поводу того, что этот термин употребляется весьма широко, поэтому иногда ис- 
пользуется и как средство мобилизации для ведения войны против других наций. Особенно важен тот факт, что масштаб влияния идеологии национализма заключается именно в его гибкости и приспосабливаемости, чему также способствует неясность и противоречивость самого понятия нации (Там же). Далее из этого проистекает то, что и масштаб распространения специфической формы национализма посредством музыки также можно понимать весьма вольно; то, что индивида или группу людей наполняет патриотическими чувствами, для других может быть нежелательно, так как они (эта другая группа) не могут соотнести себя со значением композиции. Помимо этого, всегда существует и некая доля риска, что акцентирование национального «я» в определенной степени может быть понято как угроза некой национальной инаковости.

В контексте связи национализма и культуры одного народа важно отметить, что национализм - это облик культуры, превосходящий политический стиль и доктрину (Smith, 1991). Это сплав идеологии, мифологии, символизма и сознания, который имеет глобальное влияние, в то время как нация - это вид идентичности, смысл и приоритет которой обусловливается самой формой культуры. С другой стороны, негативная коннотация усиленной формы национализма проявляется у так называемых сверх-патриотов, что представляет большую опасность, так как на самом деле речь идет об ультранационалистах, которые свой патриотизм измеряют уровнем ненависти и вражды к другим нациям, как и слепым одобрением любого политического решения и действия своего народа. Большое количество современных конфликтов подогревают националистические чувства, которые провоцируют военную «лихорадку», сопровождающуюся открытой враждой и презрением к представленному карикатурно образу врага (Caspary, 1993). Таким образом, усиленная форма национализма всегда влияет на восприятие культурных символов других наций.

Музыкальное воспевание начионального, как самый адекватный термин, который показывает многослойность и сложность феномена национального в музыке, представляет собой новое выражение относительно используемых ранее терминов нацииональный стиль или музылкальнылй национализм. Он был усвоен после того, как современные теоретические результаты мирового музыковедения возродили эту тему, которая затем была рассмотрена и дополнена в исследованиях и дискуссиях отдельных югославских авторов со ссылкой на соответствующие музыковедческие работы. Как отмечают современные музыковеды (Tomašević, 2005), понятие национального в сознании протагониста эпохи сербской музыки в период между двумя мировыми войнами имело ценность стилевого атрибута. В музыкальной практике того периода символика национального в музыке реализовывалась не только посредством специфического использования средств музыкального выражения (формы и жанра), но и определенной тематики музыкального произведения, которая включала прославление народа, полководца, героя и религии.

Именно соединение музыкальной и внемузыкальной плоскостей «Марша на Дрину» обеспечило его специфическую эстетику, которую, как форму культурного наследия, могли узнать широкие социальные слои. Благодаря деятельности многочисленных певческих обществ и оркестров, а позже и благодаря современным аранжировкам «Марша на Дрину», элементы музыкального воспевания национального со временем интегрировались в процесс дружеского времяпрепровождения как средство коммуникации, знак принадлежности или индивидуализации. Таким образом, упомянутое произведение стало примером музыкального воспевания национального, которое одновременно является и символом сербской национальной 
гордости. Этот факт становится ключевым для его актуального рассмотрения.

\section{6. «Марш на Дрину» в начале XXI века}

Несмотря на то, что «Марш на Дрину» в начале XXI века уже был неотъемлемой частью сербской традиции и культуры, оказалось, что сегодня имеет место весьма различное и даже противоречивое понимание его значения.

Самый актуальный пример конфликта мнений связан с исполнением данного произведения на праздновании Старого Нового года в ООН 13 января 2013 года, когда на концерте сербский хор Viva Vox спел этот знаменитый марш. Его исполнение вызвало скандал, так как Конгресс бошняков Северной Америки направил открытую ноту-протеста Генеральному секретарю ООН Пан Ги Муну (Ki-moon), в которой утверждалось, что данная композиция «скомпрометирована как агрессивная сербская националистическая песня», которая, помимо всего прочего, сопровождала геноцид бошняков во время войны в Боснии с 1992-го по 1995-й год ${ }^{8}$. Кроме этого, «Марш на Дрину» назвали еще и фашистской песней, которая использовалась с целью мотивации и разжигания ненависти против несербского населения. Схожим образом упомянутая композиция охарактеризована и в сообщении членов Международной экспертной комиссии Института исследований геноцида, где вообще открыто утверждается, что в начале Первой мировой войны (ранней осенью 1914 года) сербское войско при содействии черногорского совершало страшные преступления против бошняков. Также утверждается, что «Марш на Дрину» стал ясным и недвусмысленным символом геноцида, преступно совершенного над бошняками сербскими вооруженными формированиями, особенно в районе Подринье в ходе обеих мировых войн и в ходе агрессии про-

\footnotetext{
8 http://www.rts.rs/page/stories/sr/story/11/region/124 8530/protest-zbog-marsa-na-drinu-u-un.html (дата обращения: 12.06 .2019$)$
}

тив Республики Боснии и Герцеговины в период с 1992 по 1995 год.

Хотя исполнение «Марша на Дрину» в рамках празднования в ООН вызвало восторг и овации публики, и даже аплодисменты Генерального секретаря, очень быстро, после реакции бошняков, музыкальное событие стало поводом глубокого спора международного масштаба. В связи с данным инцидентом Пан Ги Мун официально выразил извинение жертвам войны, в качестве объяснения сказав, что он не был осведомлен об историческом контексте скандального произведения и о возможных последствиях его исполнения. С другой стороны, Вук Ееремич, бывший в тот момент председателем Генеральной ассамблеи $\mathrm{OOH}$, расценил письмо протеста как жалкую попытку искажения настоящего значения и смысла данной композиции. Из его кабинета сообщили, что «Марш на Дрину» является песней, которая занимает центральное место в сербской памяти о борьбе за свободу против агрессоров в Первой мировой войне, во время которой Сербия потеряла во множестве битв на стороне союзников около трети всего мужского населения. Как народ, который с гордостью чтит память этих событий, сербы имели намерение поделиться этим со всем миром посредством трансляции ясного сообщения о мире настоящим и будущим поколениям9. Таким же образом, и большие европейские концерты традиционно заканчиваются популярными маршами, которые транслируют сообщение о мире.

Множество отдельных текстов в печатных СМИ пытались пролить свет на историю «Марша на Дрину» и таким образом объяснить истоки актуального конфликта. Реакция общественности была разной, а отдельные политики и общественные деятели даже делали заявления по этому поводу. Однако форми-

\footnotetext{
9 Режим

доступа: http://www.slobodnaevropa.org/content/ban-zali-zbogmarsa-na-drinu-jeremic-tvrdi-pogresnoshvaceno/24846699.html (дата обращения: 12.06.2019)
} 
рование объективной картины ценности этого марша для сербской культуры и его истинное значение осталось в тени дискуссии, так как акцент был сделан на злоупотреблении «Маршем на Дрину» во время войн девяностых годов, и даже в начале Первой мировой войны (!).

В соответствующей литературе, связанной с Первой мировой войной, нет данных о том, что упоминаемый геноцид бошняков совершался исключительно сербским войском, при этом полностью игнорируются факты о том, что для Сербии это была не завоевательная, а оборонительная война. Когда речь идет о гражданских войнах девяностых годов, всё еще нет точных данных, но общеизвестно, что жертвы были у участников войны со всех сторон. В таких условиях сложно и необоснованно говорить о факте военных преступлений под звуки некой конкретной композиции. Мы позволим себе предположить, что тут речь прежде всего идет об установлении взаимосвязи сербского народа с определенной, национально окрашенной музыкой.

\section{7. Заключение}

Судьба музыкального произведения действительно является своеобразным феноменом, так как его путь иногда значительно отличается от предназначения, от идеи композитора и цели его создания. Это путь обусловлен социальноисторическими событиями, особенно, если речь идет о произведении, которое имеет какие-либо признаки национального. Красота произведения искусства per se не обязательно обусловлена этим контекстом, но можно сказать, что его восприятие нередко им определяется.

Переоценке «Марша на Дрину» в течение одного века способствовали изменения значения, которое он первоначально имел. Амплитуда чувств при исполнении этого марша от общенародной любви в период Первой мировой войны до нежелательности и молчаливого запрета в период социалистической Югославии, от повсеместного звучания во время национальной эйфории девяностых годов до, наконец, скандала в ООН определило его неоднозначность.

И все же «Марш на Дрину» представляет собой важную часть сербского культурного наследия, которое со временем менялось в символическом и интерпретационном смысле. Сегодня он с гордостью звучит как символ силы и борьбы за свободу, как символ героического духа сербского народа, с ясной трансляцией сообщения о мире.

\section{Перевод В. Н. Ряпухиной}

\section{Литература}

Дујовић, М. Рецепција делатности Станислава Биничког. У: др. Ивана Перковић (ур.) Музиколошка мрежа // Музикологија у мрежи. Музиколошке студије. Електронска издања. Зборник студентских радова. Београд: Факултет музичке уметности, 2014. Св. 5. С. 423-431.

Маринковић, С. Бинички и фолклор // Зборник матице српске за сценске уметности и музику. 2007. № 37. С. 7-15.

Милановић, Б. Колективни идентитети и музика // Музикологија. 2007. № 7. С. 119-134.

Caspary, W. New Psychoanalytic Perspectives on the Causes of War // Political Psychology. 1993. No. 14. Pp. 417-446.

Đurić Klajn, S. Akordi prošlosti. Beograd: Prosveta, 1981.

Đurić Klajn, S. Istorijski razvoj muzičke kulture u Srbiji. Beograd: Pro musica, 1971.

Marković, D., Kržavac, S. Zašto su smenjivani. Ljubljana: Partizanska knjiga; Beograd: Narodna knjiga, 1985.

Pavlović, M. Knjiga o himni. Gornji Milanovac: Dečje novine. 1990.

Pejović, R. Stanislav Binički kao dirigent $\mathrm{i}$ organizator muzičkog života u Beogradu. U Vlastimir Peričić (ur.) // Stanislav Binički, Zbornik radova. Beograd: Fakultet muzičke umetnosti, 1991. C. 5-54.

Peričić, V. Muzički stvaraoci u Srbiji. Beograd: Prosveta, 1969.

Puzović B. Kako je nastala pesma Marš na Drinu // Новости. 24. novembar 2013. 21:20. [Электронный pecypc] - Режим доступа: http://www.novosti.rs/vesti/naslovna/reportaze/akt uelno.293.html:465267-Kako-je-nastala-pesmaMars-na-Drinu (дата обращения: 01.09.2019) 
Smith, Anthony D. National Identity. London: Penguin, 1991.

Sociološki rečnik. Aljoša Mimica i Marija Bogdanović (prir.), Beograd: Zavod za udžbenike i nastavna sredstva, 2007.

Tomašević, K. Istok-zapad u polemičkom kontekstu srpske muzike između dva svetska rata // Музикологија. 2005. № 5. С. 119-129.

\section{References}

Caspary, W. (1993), "New Psychoanalytic Perspectives on the Causes of War", Political Psychology, 14, 417-446.

Dujovich, M. (2014), "Reception activities of the Stanislaus Benackova", in Percovich, I. (ed.), Muzykologija u mrezhi. Muzykolozhke studije. Elektronske izdanja. Zbornik studentskikh radova [Musicology online. Musikalische research. Electronic edition. Works of student works], Faculty of music, Belgrade, Serbia, 5, 423-431 (in Serb.).

Durich Klajn, S. (1971), Istorijski razvoj muzichke kulture u Srbiji [Historical development of musical culture in Serbia], Pro musica, Belgrad, Serbia (in Serb.).

Durich Klajn, S. (1981), Akordi proshlosti [Chords of the past] Prosveta, Belgrade, Serbia (in Serb.).

Marinkovic, S. (2007), "Binichki and folklore", Zbornik matitse srpske za stsenske umetnosti $i$ muzyku [materials of Matica Srpska for performing arts and music], 37, 7-15 (in Serb.).

Markovich, D., Krzhavach, S. (1985), Zashto su smenjivani [Why they changed], Partizanska knjiga, Narodna knjiga, Ljubljana, Belgrade, Serbia (in Serb.).

Milanovich, B. (2007), "Collective identity and music", Muzykologija [Musicology], 7, 119134 (in Serb.).

Pavlovich, M. (1990), Knjiga o himni [The book is about the national anthem], Dechje novine, Gornji Milanovach, Serbia (in Serb.).

Pejovich, R. (1991), "Stanislav Binichki as conductor and organizer of musical life in Belgrade", in Perichich, V. (ed.), Stanislav Binichki,
Zbornik radova [Stanislav, Proceedings], College of musical arts, Belgrade, 5-54 (in Serb.).

Perichich, V. (1969), Muzichki stvaraoci u Srbiji [Musicians in Serbia], Prosveta, Belgrade, Serbia (in Serb.).

Puzovich, B. (2013) "How the song 'The March on the Drina' came about", Novosti, November 24. [Online], available at: http://www.novosti.rs/vesti/naslovna/reportaze/akt uelno.293.html:465267-Kako-je-nastala-pesmaMars-na-Drinu (Accessed: 01.09.2019) (in Serb.).

Smith, Anthony D. (1991), National Identity, Penguin, London, UK.

Socioloshki rechnik. (2007), Aljosha Mimitsa i Marija Bogdanovich (prir.), [Alyosha Mimica and Maria Bogdanovich (prir.)], Zavod za udzhbenike i nastavna sredstva (Institute of textbooks and learning resources) Belgrade, Serbia (in Serb.).

Tomashevich, K. (2005), "East-West in the polemical context of Serbian music between the two world wars", Muzikologija [Musicology], $5,119-129$.

Информация о конфликте интересов: автор не имеет конфликта интересов для деклараций.

Conflict of Interests: author has no conflict of interests to declare.

\section{OБ ABTOPE:}

Здравич-Михайлович Даниэла, доктор наук, доцент кафедры музыкального искусства, Факультет искусств, Нишский государственный университет, ул. Кнегиње Љубице, д. 10, г. Ниш 18000, Республика Сербия; dzdravicmihailovic@yahoo.com

\section{ABOUT THE AUTHOR:}

Danijela Zdravić-Mihailović, Doctor of Sciences, Associate Professor, Department of Music Art, Faculty of Arts, University of Nis, 10 Kneginje Ljubice St., Nis 18000, Serbia; dzdravicmihailovic@yahoo.com 